\title{
THE ARAB DIGITAL GENERATION'S ENGAGEMENT WITH TECHNOLOGY: THE CASE OF HIGH SCHOOL STUDENTS IN THE UAE
}

\author{
Sara Alaleeli $(\mathbb{D}$, Ahmed Alnajjar $(\mathbb{D}$ \\ United Arab Emirates University (United Arab Emirates) \\ salalili@uaeu.ac.ae,alnajjar@uaeu.ac.ae
}

Received May 2019

Accepted June 2019

\section{Abstract}

This paper investigated the extent to which senior high school students who typified the profile of the Arab Digital Generation (ADG) engaged with technology while outside the school. Data was collected using a questionnaire that measured the extent of the students' engagement with digital technologies and their perceived media literacy. The results showed that the students had a lower frequency of engagement with digital devices for advanced purposes. Moreover, the results on the ADG and their media use patterns reflect an age characterized the generational change of technological practices and the dynamic stream of technological innovation that has occurred during the digital revolution. Given technology's established position in the lives of the ADG, knowledge on the extent of technology use and the potential social and psychological implications of plasticity can and should be harnessed to stimulate greater positive engagement of the students in a digital economy and by extension, the entirety of the UAE society.

Keywords - Arab digital generation, Media literacy, Educational technology, Emirati youth, Digital natives, Social media use.

\section{To cite this article:}

Alaleeli, S., \& Alnajjar, A. (2020). The arab digital generation's engagement with technology: The case of high school students in the UAE. Journal of Technology and Science Education, 10(1), 159-178.

https://doi.org/10.3926/jotse.756

\section{Introduction}

The global effect of digital technology leaves almost no area of society untouched. The number of global internet users has passed the 4 billion mark and people today spend around six hours daily on the Internet. About two-thirds of the world's population has a mobile phone and more than 3 billion people worldwide now use social media each month (Hootsuite, 2018). Scholars in various fields have tried to understand the scope and impact of digital technology and how far it has encroached in communities and the minds of people who use it. There is a consensus that in this era, basic literacy, while essential, is no longer sufficient to keep up with the global trend. Rather, to effectively use digital technology, there is a set of skills and processes one must be 'literate' and 'competent' in. While the older generations have been trying to adopt digital literacy and its skills, another group of people who have been consciously exposed 
to the digital world from an early age seem to have innately acquired those skills. This group is dubbed the Digital Natives or the Net Generation (Prensky, 2001).

In different regional spheres, subsets of Digital Natives also emerged. In the Arab and UAE context, the regional subset group is called the Arab Digital Generation (ADG). This article examines the extent to which senior high school students, who symbolize the Arab Digital Generation profile, engaged with technology while outside of school. This exploratory study utilizes a questionnaire and survey model along with a literature review in also understanding digital literacy and how it is present within the UAE context.

\section{Digital Literacy}

Digital Literacy as a conceptual framework refers to a multitude of complex skills or literacies that are essential in effectively using and navigating digital environments (Porat, Blau \& Barak, 2018). There are two schools of thought that perceive what digital literacy mainly encompasses. While some believe that digital literacy is mainly centered on the technical operational skills required to operate a digital device or different hardware and software (Murray \& Pérez, 2014), others believe that digital literacy is mainly centered on skills that are "cognitive, motoric, sociological and emotional" in nature (Eshet-Alkalai, 2012; $\mathrm{Ng}, 2012$ ) and is considered a knowledge set and mindset as much as it is also a skill set (Ferrari, 2012).

The skills that surround digital literacy are also referred in the literature under other umbrella terminology, particularly the term digital competence (Ferrari, 2012), despite the terms being distinct concepts. Literacy refers to "socially recognized ways of generating, communicating and negotiating meaningful content" (Lankshear \& Knobel, 2003) while competence refers to "the ability to apply knowledge and skills to different contexts, such as work, leisure, or learning" (Ala-Mutka, 2011). Digital literacy is also largely associated with other literacies that also relate to the rapidly changing development of the digital landscape such as search literacy, new literacy, media literacy, and ICT literacy (Ferrari, 2012; Lankshear \& Knobel, 2003; Ng, 2012).

The importance of digital literacy has become very apparent in the recent years. Researchers believe it is a crucial set of skills one needs to master, even going as far as dubbing it "a 'survival skill' for scholars and information consumers" (Eshet-Alkalai, 2004). On a regional scale, digital literacy has been incorporated within regional policies, particularly within Europe. According to Ferrari in his report for the European Commission (2012), "Digital Competence is both a requirement and a right of citizens, if they are to be functional in today's society". However, this does not imply that citizens are up to date or fluent in the digital literacies that would be considered essential.

\section{Digital Natives and Digital Immigrants}

The globalization of technology and its disruptive effects have stimulated the growing interest in the attributes and behaviors of the new generation. Kim and Ammeter (2018) in their review of previous works came up with the following unique characteristics of the Net-Generation: (1) they are technology savvy; (2) refinability; (3) sense of entitlement; (4) social; (5) scrutiny; (6) global orientation; (7) multitasking; (8) free expression; (9) immediate; and (10) regulation. These traits were found commonly mentioned in the works of different authors (Kim \& Ammeter, 2018: page 4).

In the context of students and the role of technology in educational institutions, the literature is largely focused on studying digital literacy by looking at the generational divide digital literacy can create, and whether this has implications on the digital literacy of two generational groups; digital natives and digital immigrants. Conceptualized by Prensky (2001), digital natives are those who grew up exposed to digital technology, which implies that they can intuitively grasp such technology without any training. On the other hand, digital immigrants refer to those who were born and brought up in an era before the inception of digital media and technology, which implies their need to 'immigrate' into the new digital era and adopt skills that is assumed to be inherent in natives. 


\begin{tabular}{|c|c|c|c|c|c|c|c|c|c|c|c|c|c|c|c|}
\hline Characters & 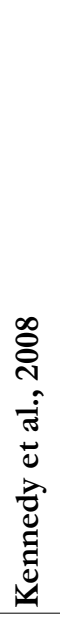 & 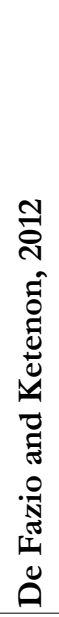 & 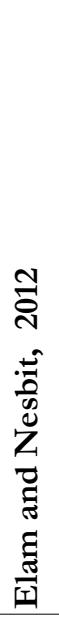 & 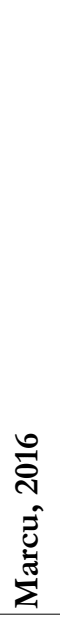 & 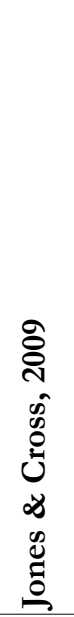 & 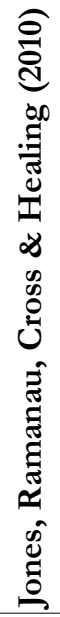 & 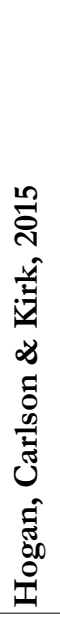 & 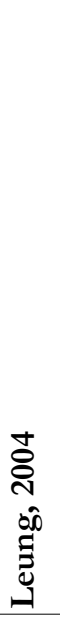 & 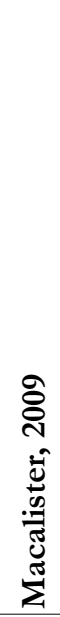 & 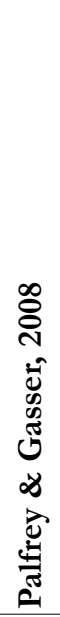 & 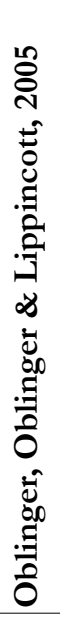 & 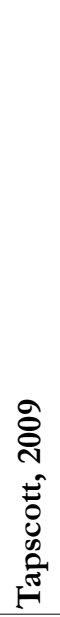 & 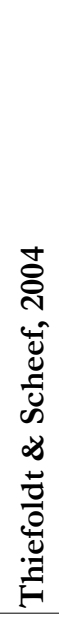 & 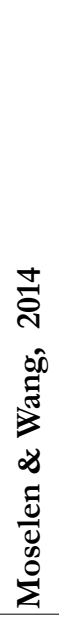 & 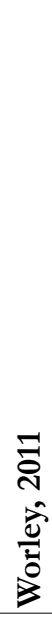 \\
\hline Technology savvy & $\mathrm{X}$ & $\mathrm{X}$ & $\mathrm{X}$ & $\mathrm{X}$ & $\mathrm{X}$ & $\mathrm{X}$ & $\mathrm{X}$ & $\mathrm{X}$ & $\mathrm{X}$ & $\mathrm{X}$ & $\mathrm{X}$ & $\mathrm{X}$ & $\mathrm{X}$ & $\mathrm{X}$ & $\mathrm{X}$ \\
\hline Refinability & $\mathrm{X}$ & $\mathrm{X}$ & $\mathrm{X}$ & & $\mathrm{X}$ & $\mathrm{X}$ & $\mathrm{X}$ & $\mathrm{X}$ & & $\mathrm{X}$ & $\mathrm{X}$ & & & $\mathrm{X}$ & $\mathrm{X}$ \\
\hline Sense of entitlement & & $\mathrm{X}$ & $\mathrm{X}$ & & & & & $\mathrm{X}$ & $\mathrm{X}$ & $\mathrm{X}$ & $\mathrm{X}$ & $\mathrm{X}$ & $\mathrm{X}$ & & $\mathrm{X}$ \\
\hline Social & $\mathrm{X}$ & $\mathrm{X}$ & $\mathrm{X}$ & $\mathrm{X}$ & $\mathrm{X}$ & & $\mathrm{X}$ & $\mathrm{X}$ & $\mathrm{X}$ & $\mathrm{X}$ & $\mathrm{X}$ & $\mathrm{X}$ & $\mathrm{X}$ & & $\mathrm{X}$ \\
\hline Scrutiny & $\mathrm{X}$ & & $\mathrm{X}$ & $\mathrm{X}$ & & & $\mathrm{X}$ & $\mathrm{X}$ & & $\mathrm{X}$ & $\mathrm{X}$ & $\mathrm{X}$ & $\mathrm{X}$ & & $\mathrm{X}$ \\
\hline Global orientation & & & & $\mathrm{X}$ & & & & $\mathrm{X}$ & $\mathrm{X}$ & $\mathrm{X}$ & $\mathrm{X}$ & $\mathrm{X}$ & & $\mathrm{X}$ & $\mathrm{X}$ \\
\hline Multitasking & $\mathrm{X}$ & $\mathrm{X}$ & $\mathrm{X}$ & $\mathrm{X}$ & & $\mathrm{X}$ & & $\mathrm{X}$ & $\mathrm{X}$ & $\mathrm{X}$ & $\mathrm{X}$ & $\mathrm{X}$ & $\mathrm{X}$ & & $\mathrm{X}$ \\
\hline Free expression & & & $\mathrm{X}$ & & & & $\mathrm{X}$ & $\mathrm{X}$ & & $\mathrm{X}$ & $\mathrm{X}$ & $\mathrm{X}$ & $\mathrm{X}$ & & $\mathrm{X}$ \\
\hline Immediate & $\mathrm{X}$ & $\mathrm{X}$ & $\mathrm{X}$ & & & & $\mathrm{X}$ & $\mathrm{X}$ & & $\mathrm{X}$ & $\mathrm{X}$ & $\mathrm{X}$ & & & $\mathrm{X}$ \\
\hline Regulation & $\mathrm{X}$ & $\mathrm{X}$ & $\mathrm{X}$ & $\mathrm{X}$ & & & & $\mathrm{X}$ & $\mathrm{X}$ & $\mathrm{X}$ & $\mathrm{X}$ & $\mathrm{X}$ & $\mathrm{X}$ & & $X$ \\
\hline
\end{tabular}

Table 1. Characteristics of the Net-Generation (Kim \& Ammeter, 2018)

Recent discourse on digital natives and digital immigrants critique this interpretation of generational differences on digital capabilities as a dangerous fallacy after a multitude of studies have been done focused on studying and analyzing the technological capabilities of students of all levels, particularly due to their status as "Digital Natives". A study by (Ramey, 2008) on undergraduate students in the United States based on the attributes of Millennials suggested by Howe and Strauss (2003) showed that students generally agreed with the characteristics assigned to the Millennial Generation. There were, however, variations in their perceptions based on the gender, ethnicity, socioeconomic status, family history of education, and geographical area of primary and secondary education.

A survey was done in Canada, which determined the extent to which college students fitted the Net Generation profile also showed that most of the descriptors of the Net Generation were evident in the students. However, there was no meaningful difference in the use of technology and learning preferences between the Net Generation and non-Net Generation students (Bullen, Morgan, Belfer \& Qayyum, 2009). The results indicated that there was no dichotomy between the Digital Natives and Digital Immigrants. A similar conclusion was also drawn from a research conducted in France, Germany, Italy, the Netherlands, Spain, Sweden which measured the extent of agreement between students and teachers on a range of learning characteristics associated with the new generation of students (Pedro, 2009). A study by Salajan, Schonwetter and Cleghorn (2010) on the attitudes students and faculty members at the University of Toronto on the implementation of digital technologies showed likewise that no distinction was drawn between the digital native students and digital immigrant faculty members. Similarly, Sanchez, Salinas, Contreras and Meyers (2010) in their study of university students in Chile found no evidence to show that the students' ICT skills were distinct from the previous generations.

A cross-cultural survey done by Lusoli and Miltgren (2009) on the 15 to 25 years' age cohort in the UK, France, Germany, and Spain showed significant differences in terms of digital culture. Independent studies 
likewise found no supporting evidence on homogeneous and radically different learning patterns among Millennial students (Ferri, Scenini, Costa, Mizzella, Cavalli \& Pozzali, 2008; Margaryan \& Littlejohn 2008; Jones, Blackey, Fitzgibbon \& Chew, 2010; van den Beemt, Akkerman \& Simons, 2010; Sanchez et al., 2010). Kennedy, Judd, Dalgarno and Waycott (2010) also provided evidence contradicting the notion about Digital Natives as being highly skilled with respect to information and communication technology. Sanchez et al., (2010) also showed that students surveyed in Chile did not manifest the skills and abilities of the Digital Natives described in the literature. A study by Thinyane (2010) with students at South African universities showed that the students were rather a heterogeneous group who have varied levels of access to most of the technologies. In China, Shao's (2010) reported that the skills levels with digital technology of a large number of university students lagged behind what is expected of the digital natives. These studies clearly challenge the grand claims made about the Net Generation being distinct from the rest of the population.

There is no doubt that the students of the Net Generation are active users of technology. Their self-reported skills with technology, however, varied significantly. In some cases, their reported information literacy had not improved despite wider access and immersion to technology (Jones, Ramanau et al., 2010). It was also found that the pervasive use of technologies by the Net Generation did not necessarily transfer to the ability to use these for learning (Schulmeister, 2008; Lorenzo, Oblinger \& Dzubian, 2006). Clearly, a disparity exists between the expected skills and the digital competence of the natives (Li \& Ranieri, 2010).

Evidence in the literature on the Net Generation and their engagement with technology show mixed results. The empirical evidence appears to point out to the reality that students' experiences with technology are far from what is expected of Digital Natives and that the advancement in digital technology in different countries did not simply translate to profound distinctive generational change.

\begin{tabular}{|l|c|c|}
\hline \multicolumn{1}{|c|}{ Author and Year } & \multicolumn{1}{|c|}{$\begin{array}{c}\text { In favor of Digital } \\
\text { Native Concept }\end{array}$} & $\begin{array}{c}\text { Against Digital } \\
\text { Native concept }\end{array}$ \\
\hline Prensky, 2001 & $\mathrm{X}$ & \\
\hline Ramey, 2008 & $\mathrm{X}$ & $\mathrm{X}$ \\
\hline Howe \& Strauss, 2003 & $\mathrm{X}$ & $\mathrm{X}$ \\
\hline Bullen et al., 2009 & & $\mathrm{X}$ \\
\hline Pedro, 2009 & & $\mathrm{X}$ \\
\hline Salajan, Schonwetter \& Cleghorn, 2010 & & $\mathrm{X}$ \\
\hline Sanchez et al., 2010 & & $\mathrm{X}$ \\
\hline Lusoli \& Miltgren, 2009 & & $\mathrm{X}$ \\
\hline Ferri et al., 2008 & & $\mathrm{X}$ \\
\hline Margaryan \& Littlejohn, 2008 & & $\mathrm{X}$ \\
\hline Jones, Ramanau et al., 2010 & & $\mathrm{X}$ \\
\hline Van den Beemt et al., 2010 & & $\mathrm{X}$ \\
\hline Kennedy et al., 2010 & & $\mathrm{X}$ \\
\hline Thinyane, 2010 & & \\
\hline Shao, 2010 & & \\
\hline
\end{tabular}

Table 2. Table showing summary of studies in favor and against students fitting with the digital native attributes

\section{Gender Bias in Digital Literacy and Digital Use}

Another way to approach digital literacy studies is to look at patterns in the digital use of the different gender groups. The literature indicates there is a gender bias in the way males and females use technology. In various sample studies around the world, there is a general consensus that found females tend to use the internet for its digital communication tools such as social media while males use internet for information, entertainment and commercial purposes, specially aspects like E-learning, gaming, and stock exchange. In addition, functions such as E-banking and E-commerce, mixed results have been observed. Typically, it was shown that gender is not a main determinant in regards to their use, but rather age, socio-economic status and digital competence were (Goswami \& Dutta, 2016). In regards to 
communication and social media use, studies show that there is a gender bias on the how it is being used. Females use social media for "maintaining existing friendships" while males use social media for "makings new friendships" (Mazman \& Usluel, 2011).

In regards to the academic use of technology, Selwyn (2008) found it was strongly influenced by gender rather than differences in technology access or expertise. McNaught, Lam \& Ho (2009) also found that gender was related to the diversity of students' digital experiences. Gender together with the socio-economic background, year grade, and disciplinary differences served as influential factors in the students' skill levels with technology (Ferri et al., 2008; Smith, Salaway \& Borreson-Caruso, 2009; Smith \& Borreson-Caruso 2010). In regards to E-learning, there have been mixed results in how the gender groups reacted to using e-learning systems. Various studies in Malaysia, Singapore and Taiwan showed that females tended to face more challenges in understanding e-learning systems compared to their male counterparts (Ong \& Lai, 2006; Islam, Rahim, Liang \& Montaz, 2011; Liaw \& Huang, 2011). A study in India showed there was no significant gender difference in e-learning use while a study in Nigeria showed females tended to use e-learning systems more than their male counterparts (Suri \& Sharma, 2013; Egbo, Okoyeuzu, Ifeanacho \& Onwumere, 2011; Goswami \& Dutta, 2016).

While the gap is closing for gender divides in countries such as the United States (Jackson, Zhao, Kolenic III, Fitzgerald, Harold \& Von Eye, 2008), there is sufficient evidence that there is a digital divide between males and females on a global scale. The literature indicates that the divide shows digital access and harnessing digital capabilities to be more favorable to males compared to their female counterparts (Goswami \& Dutta, 2016).

\section{Measuring Digital Literacy}

Across the literature, several distinct digital literacy models have been widely cited. One empirically tested framework was proposed by van Deursen. This model initially identified four types of practical skills that can be used to measure digital literacy (van Deusen, 2010); 1) operational skills, the ability to use and handle computer and Internet software and hardware; 2) formal skills, which are needed in understanding and using formal characteristics of computer and Internet, such as file structures, hyperlinks and navigating through the internet; 3) information skills, or the skills required to search, select, handle and assess digital media contents; 4) strategic skills, or the ability to pre-actively manipulate and navigate the digital landscape in order to attain certain personal desires or information.

Later, two more categories were added to this model to accommodate to the increasing social function of the digital landscape (van Deursen, Helsper \& Eynon, 2014). These are: 5) communication skills, or the ability to participate in online networks and social platforms and effectively communicate with others through the Internet and 6) content creation skills, or the ability to create and distribute content on digital platforms.

In 2015, an updated framework and scale was proposed to examine five types of internet skills; operational, information navigation, social, creative, and mobile. These skills were incorporated into what is now called the Internet Skills Scale (ISS) that is adjusted to study digital literacy and internet skills in general population sample studies (2016).

Another model cited in the literature is the digital literacy framework conceptualised by Eshet-Alkalai (2012), which comprises of six skills that emphasize the cognitive and emotional aspects of digital literacy. These skills include; 1) photo-visual literacy, which is the ability to interpret messages presented in the visual-graphical form, 2) reproduction literacy, or the ability to create new meanings and messages by combining pre-existing forms of media and information, 3) branched literacy or hypermedia skills is the ability to have spatial-multidimensional orientation skills that allows one to construct and acquire meaningful understanding in nonlinear but coordinated navigation of the digital spaces, 4) informational literacy refers to the ability to critically analyze, identify and differentiate between online information and sources that is credible or non-credible, 5) social emotional literacy, or the ability to engage in cyberspace 
through digital communication, constructing an online persona, expressing a range of emotions, understanding the 'rules' of the digital space and identifying deception and risks in the digital space, and 6) real-time thinking literacy, which is the ability to effectively process large, simultaneous fluxes of information at a high speed.

Another framework for digital competence was published by the European Commission Joint Research Centre. The model identifies three aspects; 1) instrumental knowledge and skills, needed to use digital equipment software, media and other essential skills. Instrumental knowledge and skills serve as a basis for developing 2) advanced knowledge and skills, which is used for more sophisticated aspects such as applying digital tools to certain tasks, communication, networking and collaboration and 3) attitudes represent the mindset and behavior one has in digital environments, which in turn shapes the way one uses the above-mentioned skills in intercultural, critical, creative, independent responsible ways (Ala-Mutka, 2011; Porat et. al, 2018).

Another framework is conceptualized by Erstad (2015). Erstad explores the concepts of media literacy and digital literacy as two closely connected areas in terms the use of digital media and technology use in both. He also explores how should one's understanding in these areas should be measured. In his study, Erstad highlights the components of media/digital literacy and elaborates how each component is carried out as a practical function. These components include basic skills, download, search, navigate, classify, integrate, evaluate, communicate, cooperate and create. These components are identified to contribute to five dimensions that represent different focus areas of research on school-based studies of media literacy. These include: 1) Basic skills, 2) Media as an object of analysis, 3) Knowledge building in subject domains, 4) Learning strategies and 5) Digital Bildung/Cultural competence.

\section{Theoretical Framework of this Research Study}

Essentially, this study is informed by the framework of van Deursen and Erstad, which both identify clear dimensions within digital literacy that can be measured and studied. Van Deursen's literature was used for mostly theoretical and preliminary research purposes. It provided an elaborate theoretical outlook that allowed us to clearly map digital literacy and its components as a theoretical concept and its practical uses within the context of mobile, internet and computer usage. Erstad's survey model and literature (2015) recognizes literacy dimensions for school-based studies and technology in the educational context which seemed appropriate for this study considering our student sample group. Additionally, Erstad's article identifies different aspects and categories within media/digital literacy that was adapted as a basis for the second survey that was used in this research study.

\section{Context of the Study}

\subsection{The Arab Digital Generation}

In 2012, Booz \& Company reported the emergence of a new generation in the Middle East and North Africa and named it the Arab Digital Generation (ADG). Accordingly, the ADG comprise Internet users ages 15 to 35 who are digitally active; own a laptop, computer, or smartphone; access the Internet multiple times each day; and have at least one account on a social network. It was purported that the predisposition of the ADG to new technology will have the potential of affecting societal institutions in unprecedented ways (Sabbagh, Mourad, Kabbara, Shehadi \& Samman, 2012: page 9).

At best, the ADG is a geographic reflection of a pre-existing generational phenomenon that is marked by the arrival of a new generation on the global landscape. Due to its worldwide occurrence, various authors have identified this new generation by a myriad of proto-terms such as the Millennial Generation (Howe \& Strauss.1991); Generation Y (Brosdahl \& Carpenter, 2011); Net Generation (Tapscott, 1998); Digital Natives (Prensky, 2001); and Generation Z (Singh \& Dangmei, 2016), among others. Currently, a variety of other terms appear in the literature which identifies the new generation with specific defining activities. Some of these terms include the IM (Instant Messaging) Generation (Lenhart, Rainie, \& Lewis, 2001); Gamer Generation (Carsten \& Beck, 2005); Homo Zappiens (Veen, 2003); Google Generation (Rowlands, 
Nicholas, Williams, Fieldhouse, Gunter, Withey et al. 2008); i-Generation (Rosen, 2010) and Generation C generation (Friedrich, Peterson, Koster \& Blum, 2010), which stands for connected, communicating, content-centric, computerized, community-oriented, and always clicking among others. Geographic variants for the new generation have also emerged such as the China Digital Generation (Schultz, Block, \& Schultz, 2013), Afrillennials (Gilbert, 2018); and New Arab (Cole, 2015), to name a few. Coming hand in hand with all these are the corresponding descriptors, attributes, behaviors, and orientations of the people who characterize the generation.

The Millennials in the UAE have merited some attention in the literature especially in relation to human resources in the workplace but there is a dearth of studies that focus on this new generation in the educational context. One of the goals of the UAE is to prepare the population for a digital economy. In response, educational reforms have been initiated in the UAE educational system to prepare students for active roles, engagement, and participation in such an economy. It has been observed though that literature pertinent to the preparation of students in the UAE focused more on classroom technology (Vrazalic, MacGregor, Behl \& Fitzgerald, 2009; Iran, 2011; Alkaabia, Albion \& Redmond, 2016; Srivastava \& Rauta, 2017) rather than on the users of these technologies. While there were some studies that mentioned Digital Natives in the UAE, these studies centered mainly on technology than on the Digital Natives (Ashraf \& Perez-Vega, 2015; Grigoryan \& Babayan, 2015).

One study that gave impetus to the Digital Natives in the UAE educational context is that of Martin (2013). She explored the digital engagement of tertiary students in the UAE and noted the substantial impact of the recent technological changes in the country on the youth. Overall, Emirati students in her study demonstrated better access to digital technologies than in many other countries, but that they are less likely to be considered Digital Natives, as their engagement with these technologies had largely only been active since attendance at tertiary education (Martin, 2013: page 169). Hence, she concluded that the engagement of Emirati college students with digital technologies is widespread but at an unsophisticated level. Among others, the study provided a snapshot of the engagement of Emirati college students with digital technology based on empirical data rather than anecdotal evidence or sweeping generalizations (Martin, 2013). It still remains though that there is a dearth of research into the Emirati youths' manifestation of characteristics attributed to digital natives such as constant engagement with, and high levels of confidence and skill when dealing with a wide variety of digital technologies (Martin, 2013: page 40).

The foregoing stimulated the interest of the authors of this paper to further contribute empirical information to the discussion on the engagement of the current generation of Arabic students with digital with technology in the UAE. This paper, however, focused on senior high school students and adopted the assumption that the ADG has ubiquitous access to digital technologies and services in the UAE (Sabbagh et al., 2012; Hootsuite, 2018) which accounts for the widespread engagement with such technologies (Martin, 2013). Based on these assumptions, this paper explored the extent to which the senior high school students who typified the profile of the ADG used digital technologies and described their perceived level of media literacy.

\subsection{United Arab Emirates: Technology and Educational Reform}

In the Middle East, the United Arab Emirates (UAE) is among the most technologically advanced markets in the region and a leading country at the forefront of the digital transformation, particularly for e-commerce, AI technology and smart learning development. With a population of 9.47 million in January 2018, 99\% consisted of internet users and active social media users, respectively. Furthermore, 77\% comprised of unique mobile users and $92 \%$ are active mobile social users (Hootsuite, 2018).

While the UAE have implemented technology integration in a strategic way, these movements were not accompanied necessarily accompanied with sufficient systematic education on these new systems for most of the 2000s. The missing link was the need for the country to reconcile the UAE's culture with digital literacy and learning (Jewels \& Albon, 2011). Due to the profound effect of the digital transformation on peoples' behaviors, Becerra (2017) argued that the digital revolution is not about technology per se - it's 
about people. The people dimension is emerging as the key to unlocking the value of these transformations and ensuring the sustainability of the changes. Widespread access to technology was only the first step of the process. However, the people now need to be educated on the effective usage of this technology. The Digital Natives, or the Arab Digital Generation (ADG) in this context, are especially caught in this clash between this widespread access and insufficient digital education. Jewels and Albon argue this issue might hinder the ADG "from acquiring all the skills that will ultimately contribute to them being digitally literate in a global environment" (Jewels \& Albon, 2011).

Subsequently, the integration of E-learning technology in educational institutions has been a growing research field globally, to ensure the enforcement of digital literacy among the youth. In the context of the UAE, much of the early implementations of technology in educational institutions in the UAE took place in tertiary level institutions. This movement towards establishing 'laptop universities' and e-learning inclined education started with Zayed University in 1995 and were quickly followed by other public and private universities into the 2000s (Parkman, Litz \& Gromik, 2018).

For K-12 school institutions in the UAE, the prospect of e-learning at the school level is a very recent idea. The UAE have increasingly geared its educational system under the strong consideration of national strategic initiatives visions, that seek to improve and reform the educational sector as well as other national sectors. These initiatives essentially focus on the premise of innovation, technology integration and advancement in research, through the development of 21 st century skills of its nationals. Since these are primarily government led movements, UAE's push for smart education has put them at the forefront in the global educational field.

The initial smart learning developments in K-12 schools can be exemplified by the establishment of the Mohammed Bin Rashid Smart Learning Program (MBRSLP) in 2012 (UAE Cabinet, 2019). A collaborative venture with the Prime Minister's office, Ministry of Education and the UAE Telecommunications Regulatory Authority, it aims to introduce 'Smart Classes' in national schools which students will utilize smart devices and high speed $4 \mathrm{G}$ networks in their learning process. This initiative aims to create a new and enhanced e-learning environment that involves a revised specialized curricula and the active engagement of teachers, students and parents.

In 2013, the Abu Dhabi Education Council (ADEC) began to implement a reform plan across public schools in the Abu Dhabi emirate (Olivia, 2013). The plan introduced the New School Model (NSM), which is conceptualized in order to support its students in an inquiry-based, student centered and technology classroom environment. To complement its technology rich curriculum, schools across Abu Dhabi were equipped with computers, portable devices and high-speed internet. In addition, a new website for student record access and grades were released for teachers, parents and administrators (Parkman et al., 2018).

All these developments contribute to the Education 2020 Strategy, a plan conceptualized by the UAE Ministry of Education. Along with reforms to curriculum and standardization of the UAE Teacher Licensing, are efforts towards increased digital literacy and e-learning. In light of this strategy, research focused on dynamics in UAE schools and UAE students is crucial in understanding how to approach this Strategy's aims effectively (Ministry of Education, 2010; Export.gov, 2019).

\section{Methods}

\subsection{Sample}

The study sample consisted of 222 Emirati senior students randomly selected from three branches of a private school in Abu Dhabi. Of the total sample, 112 are females and 110 are males. The selection criteria included ownership of a mobile device, computer, 24/7 internet access, and at least an account in social media. The criteria were based on the purported characterization of the ADG (Sabbagh et al., 2012) which implied ubiquitous ownership and access to digital technology and services. All the participants were clearly 
briefed on the purpose of the research and consent was granted from the participants. Ethical clearance was also obtained from various educational authorities in the country before undertaking the study.

\subsection{Research Instrument}

This paper used the questionnaire to gather the research data. The first part of the questionnaire was a Likert scale that measured the extent to which the students engaged with digital technologies outside the school for the duration of their senior high school year. This was based on an instrument reportedly developed by Kennedy, Dalgarno, Bennet, Judd, Gray and Chang (2008) and simplified by Martin (2013) to suit the Emirati respondents whose first language is not English. The second part of the instrument was a Likert scale that measured the self-perceived media literacy of the respondents. This was based on the categories of media literacy proposed by Erstad (2015) which was accordingly simplified to suit the respondents. The research instrument was pre-tested to a group of twenty (20) high school students who did not form part of the study sample as they were from another high school in the locality. The result of the pre-test using Spearman-Brown, $r=.875$, indicated a high instrument reliability.

\subsection{Procedures}

The survey was conducted during the two days of graduation rehearsal time of the senior students in May 2017. This data gathering was done during these occasions as this was the most opportune time for all the senior students from the three geographically separated school branches were together. Accordingly, the questionnaires were administered to the students in coordination with the IT faculty of the school and were immediately retrieved after these were voluntarily accomplished by the students.

The results of the survey were descriptively analyzed based on the weighted means of the items and the ttest was used to determine significant differences in the response of the male and female students.

\section{Results and Discussion}

The following shows the extent to which the high school students used a variety of digital technologies outside the classroom for the duration of their senior year in high school; the difference in the extent of use of digital technologies; and their perceived media literacy.

Mobile device use. Table 3 shows the extent to which the students used their mobile devices relative to basic and advanced activities. Accordingly, it can be noted that there is a similar trend in the extent of use of mobile devices between the male and female students.

On the whole, the results also show that most of the time both male and female students depended on their mobile devices for basic use $(\mathrm{M}=4.45)$ but seldom depended on their mobile devices for advanced activities $(\mathrm{M}=2.67)$. Two possible factors account for the low extent of use of the students' mobile devices for advanced purposes. First, most of the students do not depend on the GPS because most of them are simply familiar with the locality or are chauffeured by their parents or family drivers to the school or other destinations of their choice. Second, as a matter of school policy, bringing mobile devices to the classroom is prohibited by the school hence the students never used their mobile devices to copy notes or to record a lecture.

The use of computers. Table 4 shows the extent to which the students used their computers for basic and advanced activities. 


\begin{tabular}{|l|c|c|c|c|c|c|}
\hline \multicolumn{1}{|c|}{ Use of mobile device } & $\begin{array}{c}\text { Males } \\
(\mathbf{n = 1 1 0})\end{array}$ & Extent* & $\begin{array}{c}\text { Females } \\
(\mathbf{n = 1 1 2})\end{array}$ & Extent & Overall & Extent \\
\hline 1. Call, text, or tweet people & 4.92 & A & 4.84 & A & 4.88 & A \\
\hline 2. To take photos & 4.80 & A & 4.76 & A & 4.78 & A \\
\hline 3. To send photos & 4.80 & A & 4.76 & A & 4.78 & A \\
\hline 4. To download games, movies, or videos & 4.00 & O & 3.96 & O & 3.98 & O \\
\hline 5. To send or receive email & 3.84 & O & 3.88 & O & 3.86 & O \\
\hline 6. To access information, apps, or services & 3.96 & O & 3.84 & O & 3.90 & O \\
\hline 7.For GPS navigation or maps services & 2.76 & SEL & 2.80 & SEL & 2.78 & SEL \\
\hline 8. To record a lecture or take study notes & 1.20 & N & 1.48 & N & 1.34 & N \\
\hline Overall & 3.78 & O & 3.79 & O & 3.78 & O \\
\hline The extent of basic use (Items 1-5) & 4.47 & A & 4.44 & A & 4.45 & A \\
\hline The extent of advanced use (Items 6 -8) & 2.64 & SEL & 2.71 & SEL & 2.67 & SEL \\
\hline
\end{tabular}

*Abbreviations: Never (N); Seldom (SEL); Sometimes (S); Often (O); Always (A).

Table 3. The extent of use of a mobile device $(\mathrm{N}=222)$

\begin{tabular}{|l|c|c|c|c|c|c|}
\hline \multicolumn{1}{|c|}{ Use } & $\begin{array}{c}\text { Males } \\
(\mathbf{n = 1 1 0 )}\end{array}$ & Extent* & $\begin{array}{c}\text { Females } \\
(\mathbf{n = 1 1 2})\end{array}$ & Extent & Overall & Extent \\
\hline 1. Create presentation and organize information & 3.76 & $\mathrm{O}$ & 3.68 & $\mathrm{O}$ & 3.72 & $\mathrm{O}$ \\
\hline 2. To play and listen to audio files & 3.88 & $\mathrm{O}$ & 3.64 & $\mathrm{O}$ & 3.76 & $\mathrm{O}$ \\
\hline 3. To view video files & 4.64 & $\mathrm{~A}$ & 3.76 & $\mathrm{O}$ & 4.20 & $\mathrm{~A}$ \\
\hline 4. To play video games & 4.68 & $\mathrm{~A}$ & 2.36 & $\mathrm{SEL}$ & 3.52 & $\mathrm{O}$ \\
\hline 5. To create or edit audio or video files & 3.40 & $\mathrm{O}$ & 2.44 & $\mathrm{SEL}$ & 2.92 & SEL \\
\hline 6. To manage or manipulate digital photos & 3.76 & $\mathrm{O}$ & 3.80 & $\mathrm{O}$ & 3.78 & $\mathrm{O}$ \\
\hline Overall & 4.02 & $\mathrm{O}$ & 3.28 & $\mathrm{~S}$ & 3.65 & $\mathrm{O}$ \\
\hline The extent of basic use (Items 1-4) & 4.24 & $\mathrm{~A}$ & 3.36 & $\mathrm{~S}$ & 3.8 & $\mathrm{O}$ \\
\hline The extent of Advanced use (Items 5-6) & 3.58 & $\mathrm{O}$ & 3.12 & $\mathrm{~S}$ & 3.35 & $\mathrm{~S}$ \\
\hline
\end{tabular}

*Abbreviations: Never (N); Seldom (SEL); Sometimes (S); Often (O); Always (A).

Table 4 . The extent of the use of computers $(\mathrm{N}=222)$

\begin{tabular}{|l|c|c|c|c|c|c|}
\hline \multicolumn{1}{|c|}{ Use } & $\begin{array}{c}\text { Males } \\
(\mathbf{n = 1 1 0 )}\end{array}$ & Extent* & $\begin{array}{c}\text { Females } \\
(\mathbf{n = 1 1 2})\end{array}$ & Extent & Overall & Extent \\
\hline 1. To send or receive email & 3.80 & $\mathrm{O}$ & 3.72 & $\mathrm{O}$ & 3.76 & $\mathrm{O}$ \\
\hline 2. For chatting & 3.32 & $\mathrm{~S}$ & 3.36 & $\mathrm{~S}$ & 3.34 & $\mathrm{~S}$ \\
\hline 3. To listen to a sound recording & 3.44 & $\mathrm{O}$ & 3.36 & $\mathrm{~S}$ & 3.40 & $\mathrm{O}$ \\
\hline 4. To use social networking & 3.64 & $\mathrm{O}$ & 3.72 & $\mathrm{O}$ & 3.68 & $\mathrm{O}$ \\
\hline 5. to download materials & 4.76 & $\mathrm{~A}$ & 4.80 & $\mathrm{~A}$ & 4.78 & $\mathrm{~A}$ \\
\hline 6. To read and comment on the online content & 3.64 & $\mathrm{O}$ & 3.72 & $\mathrm{O}$ & 3.68 & $\mathrm{O}$ \\
\hline 7. to look up general information & 3.40 & $\mathrm{O}$ & 3.92 & $\mathrm{O}$ & 3.66 & $\mathrm{O}$ \\
\hline 8. to look up reference information & 3.68 & $\mathrm{O}$ & 3.96 & $\mathrm{O}$ & 3.82 & $\mathrm{O}$ \\
\hline 9.To use a learning management system & 1.48 & $\mathrm{~N}$ & 1.20 & $\mathrm{~N}$ & 1.34 & $\mathrm{~N}$ \\
\hline 10.To build and maintain a website & 1.56 & $\mathrm{~N}$ & 1.28 & $\mathrm{~N}$ & 1.42 & $\mathrm{~N}$ \\
\hline 11. to publish or add video and photo files & 3.32 & $\mathrm{~S}$ & 3.44 & $\mathrm{~S}$ & 3.38 & $\mathrm{~S}$ \\
\hline 12. To create and maintain own personal blog & 1.36 & $\mathrm{~N}$ & 1.20 & $\mathrm{~N}$ & 1.28 & $\mathrm{~N}$ \\
\hline 13. To buy or sell & 1.12 & $\mathrm{~N}$ & 1.60 & $\mathrm{~N}$ & 1.36 & $\mathrm{~N}$ \\
\hline 14. For financial services & 1.32 & $\mathrm{~N}$ & 1.28 & $\mathrm{~N}$ & 1.30 & $\mathrm{~N}$ \\
\hline Overall & 2.84 & $\mathrm{~S}$ & 2.89 & $\mathrm{~S}$ & 2.87 & $\mathrm{~S}$ \\
\hline The extent of basic use (Items 1 -8) & 3.77 & $\mathrm{O}$ & 3.70 & $\mathrm{O}$ & 3.74 & $\mathrm{O}$ \\
\hline The extent of advanced use (Items 9-14) & 2.16 & $\mathrm{SEL}$ & 2.24 & $\mathrm{SEL}$ & 2.20 & SEL \\
\hline
\end{tabular}

*Abbreviations: Never (N); Seldom (SEL); Sometimes (S); Often (O); Always (A).

Table 5. The extent of use of the internet $(\mathrm{N}=222)$ 
The results further show that most of the time, the males $(M=4.42)$ depended on their computers for basic uses while the females $(M=3.36)$ only sometimes depended on their computers for basic use. While males $(\mathrm{M}=3.58)$ often depended on their computers for advanced use, females $(\mathrm{M}=3.12)$ only sometimes used their computers for advanced activities. The results generally indicate that males have a higher extent of use of the computer compared to females

Internet use. Table 5 shows the extent to which the students used the internet in performing basic and advanced activities. It can be noted that there is a similarity trend between males and females in terms of the extent to which they used the Internet. One of the differences between the two groups is that males $(\mathrm{M}=3.44)$ often used the Internet to listen to the sound recording while females only sometimes engaged in this activity using the Internet $(\mathrm{M}=3.36)$.

In terms of the basic and advanced uses of the internet, both the male $(M=3.77)$ and female $(M=3.70)$ students reported that they often used the Internet for basic activities and both males $(M=2.16)$ and females $(M=2.24)$ seldom used the Internet for advanced activities

The difference in the basic and advanced uses of digital technology. Table 6 shows the difference in the basic uses of digital devices by both male and female students. Accordingly, there is no significant difference between the male $(M=4.47, S D=1.04)$ and female $(M=4.44, S D=0.91)$ students in terms of the basic use of their mobile devices, $\mathrm{t}(221)=0.102, \mathrm{p}=0.459$. Similarly, the male $(\mathrm{M}=3.77, \mathrm{SD}=1.33)$ and female $(\mathrm{M}=3.78, \mathrm{SD}=1.40)$ students do not significantly differ in the basic use of the internet, $\mathrm{t}(221)=-0.044, \mathrm{p}=.482$. However, the male $(\mathrm{M}=4.24, \mathrm{SD}=0.71)$ and female $(\mathrm{M}=3.36, \mathrm{SD}=1.34)$ students significantly differ in the basic use of the computer, $t(221)=2.126 . \mathrm{p}=0.038$. This can be because of the more frequent use of the computer for playing video games among males compared to females as shown in Table 3

Table 7 shows the difference in the basic uses of digital devices by both male and female students. Accordingly, there is no significant difference between the male $(\mathrm{M}=2.64, \mathrm{SD}=3.83$ and female $(\mathrm{M}=2.71$, $\mathrm{SD}=2.80)$ students in terms of the advanced use of their mobile devices, $\mathrm{t}(221)=-0.063, \mathrm{p}=0.474$. The male $(\mathrm{M}=3.53, \mathrm{SD}=0.060)$ and female $(\mathrm{M}=3.12, \mathrm{SD}=0.920)$ students do not significantly differ in the advanced use of the computer $\mathrm{t}(221)=0.653, \mathrm{p}=0.473$. Finally, the male $(\mathrm{M}=2.16, \mathrm{SD}=8.44)$ and female $(\mathrm{M}=2.24, \mathrm{SD}=1.64)$ students do not significantly differ in the advanced use of the Internet, $\mathrm{t}(221)=-0.133$. $\mathrm{P}=0.446)$.

Except for the activity of playing video games on the Internet, the foregoing results indicate that the more frequent use of digital devices for basic activities and the less frequent use of these devices for advanced activities are not gender-specific.

Self-perceived media literacy. Table 8 shows the perceived media literacy of the male and female students. Whereas the level of literacy varies according to activity, it can be noted that there is a similarity in the trend of each group with the sample means relative to these activities.

On the whole, the result portray the students as having excellent basic (item 1) and downloading (item 2) skills and are very good at searching information (item 3); navigating the web (item 4); classifying information (item 5); integrating information (item 6); communicating information (item 8); and collaborating (item 9) online. Finally, they are good at evaluating information (item 7) and producing and creating different forms of information (item 10).

Difference in the perceived media literacy. Table 9 shows that there is no significant difference between the male and female students in terms of their perceived skills to download, $t(221)=1.389$, $\mathrm{p}=0.083$; search, $\mathrm{t}(221)=0.252, \mathrm{p}=0.400$; navigate, $\mathrm{t}(221)=0.191, \mathrm{p}=0.421$; classify, $\mathrm{t}(221)=0.118, \mathrm{p}=0.455$; integrate, $\mathrm{t}(221)=0.261, \mathrm{p}=0.403$; evaluate, $\mathrm{t}(221)=0.017, \mathrm{p}=0.493$; communicate, $\mathrm{t}(221)=9.095, \mathrm{p}=0.464$; cooperate, $\mathrm{t}(221)=0.085, \mathrm{p}=0.467$; and create, $\mathrm{t}(221)=0.153, \mathrm{p}=0.442$. 
On the whole, the results indicate that the perceived media literacy of the students is not gender - specific. It shows that regardless of gender, the perceived literacy regarding specific skills was on the same level for both groups of students.

\begin{tabular}{|l|c|c|c|c|c|c|c|}
\hline \multicolumn{1}{|c|}{ Basic } & $\begin{array}{c}\text { M } \\
\text { (male) }\end{array}$ & SD & $\begin{array}{c}\text { M } \\
\text { (female) }\end{array}$ & SD & t & Df & P \\
\hline Mobile use & 4.47 & 1.04 & 4.44 & 0.91 & 0.102 & 221 & 0.459 \\
\hline Computer use & 4.24 & 0.71 & 3.36 & 1.34 & 2.126 & 221 & 0.038 \\
\hline Internet use & 3.77 & 1.33 & 3.78 & 1.40 & -0.044 & 221 & 0.482 \\
\hline
\end{tabular}

Table 6 . The difference in the basic use of digital devices

\begin{tabular}{|l|c|c|c|c|c|c|c|}
\hline \multicolumn{1}{|c|}{ Basic } & $\begin{array}{c}\mathbf{M} \\
\text { (male) }\end{array}$ & SD & $\begin{array}{c}\text { M } \\
\text { (female) }\end{array}$ & SD & t & Df & P \\
\hline Mobile use & 2.64 & 3.83 & 2.71 & 2.80 & -0.063 & 221 & 0.474 \\
\hline Computer use & 3.53 & 0.06 & 3.12 & 0.92 & 0.653 & 221 & 0.473 \\
\hline Internet use & 2.16 & 8.44 & 2.24 & 1.64 & -0.133 & 221 & 0.446 \\
\hline
\end{tabular}

Table 7 . The difference in the advanced use of digital devices

\begin{tabular}{|c|c|c|c|c|c|c|}
\hline Literacy & $\begin{array}{c}\text { Males } \\
(n=110)\end{array}$ & Level* & $\begin{array}{c}\text { Females } \\
(n=112)\end{array}$ & Level & Overall & Level \\
\hline $\begin{array}{l}\text { 1. Be able to open software, sort out and save } \\
\text { information on the computer, and other simple } \\
\text { skills in using the computer } \\
\text { 2. Be able to download different information } \\
\text { types from the internet. } \\
\text { 3. Know about and how to get access to } \\
\text { information } \\
\text { 4. Be able to orient oneself in digital networks, } \\
\text { learning strategies in using the internet } \\
\text { 5. Be able to organize information according to } \\
\text { certain classification schemes } \\
\text { 6. Be able to compare and put together different } \\
\text { types of information } \\
\text { 7. Be able to judge the quality, relevance, } \\
\text { objectivity, and usefulness of information } \\
\text { found } \\
\text { 8. Be able to communicate information and } \\
\text { express oneself through different mediational } \\
\text { means } \\
\text { 9. Be able to take part in net-based interactions } \\
\text { 10. Be able to produce and create different forms } \\
\text { of information or develop something new by } \\
\text { using specific tools and software }\end{array}$ & $\begin{array}{l}5.00 \\
4.86 \\
3.94 \\
3.70 \\
3.44 \\
3.36\end{array}$ & $\begin{array}{c}\mathrm{E} \\
\mathrm{E} \\
\mathrm{VG} \\
\mathrm{VG} \\
\mathrm{VG} \\
\mathrm{VG}\end{array}$ & $\begin{array}{l}5.00 \\
4.80 \\
3.92 \\
3.65 \\
3.43 \\
3.33\end{array}$ & $\begin{array}{c}\mathrm{E} \\
\mathrm{E} \\
\mathrm{VG} \\
\mathrm{VG} \\
\mathrm{VG} \\
\mathrm{VG}\end{array}$ & $\begin{array}{l}4.83 \\
3.93 \\
3.67 \\
3.43 \\
3.34\end{array}$ & $\begin{array}{c}\mathrm{E} \\
\mathrm{E} \\
\mathrm{VG} \\
\mathrm{VG} \\
\mathrm{VG} \\
\mathrm{VG}\end{array}$ \\
\hline Overall & 2.85 & G & 2.89 & G & 2.87 & G \\
\hline
\end{tabular}

Table 8. Self-perceived media literacy 


\begin{tabular}{|l|c|c|c|c|c|c|c|}
\hline \multicolumn{1}{|c|}{ Literacy } & $\begin{array}{c}\text { M } \\
\text { (male) }\end{array}$ & SD & $\begin{array}{c}\text { M } \\
\text { (female) }\end{array}$ & SD & t & Df & P \\
\hline 1. Download & 4.86 & 0.01 & 4.80 & 0.03 & 1.389 & 221 & 0.083 \\
\hline 2. Search & 3.94 & 0.04 & 3.92 & 0.01 & 0.252 & 221 & 0.400 \\
\hline 3. Navigate & 3.70 & 0.08 & 3.65 & 0.33 & 0.191 & 221 & 0.421 \\
\hline 4. Classify & 3.44 & 0.03 & 3.43 & 0.02 & 0.118 & 221 & 0.455 \\
\hline 5. Integrate & 3.36 & 0.03 & 3.33 & 0.07 & 0.261 & 221 & 0.403 \\
\hline 6. Evaluate & 3.19 & 1.10 & 3.18 & 0.89 & 0.017. & 221 & 0.493 \\
\hline 7. Communicate & 3.51 & 0.02 & 3.50 & 0.04 & 0.095 & 221 & 0.464 \\
\hline 8. Cooperate & 3.45 & 0.01 & 3.44 & 0.07 & 0.085 & 221 & 0.467 \\
\hline 9. Create & 2.70 & 0.54 & 2.64 & 0.47 & 0.153 & 221 & 0.442 \\
\hline
\end{tabular}

Table 9. The difference in perceived literacy

\section{Discussion}

The high school students in this paper typify the profile of the ADG in so far as the specific attributes suggested by Sabbagh et al. (2012) are concerned namely, the ubiquitous ownership of digital devices and access to digital technology and services. This makes the students' active use of technology outside the classroom evident. The results point out that the students' constant engagement with different digital technologies for basic purposes is done with some level of confidence and skill. They, however, perceived that their skill level in the use of digital technology for some advanced purposes was lower. This supports the findings of earlier studies on the skills of Digital Natives on the use of technology (Martin, 2013; Sanchez et al., 2010; Kennedy et al., 2010; Shao, 2010). It can be deduced from the results presented in this paper that the ADG to some extent reflects some of the traits of the Digital Natives. The other attributes of the digital culture of the Digital Natives, however, are beyond the scope of this paper.

What can be further inferred from the results is that the ADG are typically screenagers (Tapscott, 2009) whose perception of the social world is partly shaped by the digital space that they are constantly exposed to. Digital space in this context refers to the content of what is displayed on the screen of digital devices which varies in scope, diversity, and form (Di Cesare, Harwood, \& Rowsell, 2016). In this regard, the information and digital content that they freely choose and control can be overwhelming depending on their frequency of engagement. It can be further inferred that the behavior of the high school students more likely approximates that of Generation C which stands for connected, communicating, content-centric, computerized, community-oriented, and always clicking (Friedrich et al., 2010).

The frequency of the students' engagement with digital technology can have socio-psychological consequences. There is the possibility that the frequency of use will lead to a fixation with digital space which can be a potential barrier to real-time interaction in the social world. It has been found that the volatility of social behavior among teens can be influenced directly by their engagement in online digital spaces (Santrock, 2008). The frequent use of digital technology can lead to a social deficit among Digital Natives hence they were reported to lack social skills. The problem, however, is more than the social impact of technology because frequent use can also involve changes in the brain of the user (Small \& Vorgan, 2009).

Some authors argued that digital experience which is shaped by frequent use of technology has the capacity to rewire the brain. (Johnson, 2006; Doige, 2007; Small \& Vorgan, 2009; Arden, 2010) and the increasing use of digital materials can force the brain into an evolutionary process (Small \& Vorgan, 2009). The conception of the brain as hardwired to function in predetermined ways is now challenged by the contrasting notion that the brain is soft-wired by experience - that the brain is modified by experience throughout one's lifetime and is changing at all times (Arden, 2010). The term that is used to describe the 
malleability of the brain is neuroplasticity. Neuroplasticity has demonstrated that the brain changes with every activity it performs (Doige, 2007).

It was suggested that neuroplasticity can render the brain to be more resourceful yet vulnerable to outside influences. While it can increase flexibility, neuroplasticity can also lead to rigidity (Doige, 2007). While it can increase attentiveness to digital space, it can also lead to attention deficiency and lack of focus because of the overwhelming amount of digital content (Arden, 2010). Arden (2010) explained that all the flashing images in the media can diminish the orientation response of the user to the novel and significant information hence, can be both exhausting and addictive.

\section{Limitations and Future Research}

This study's findings should be read in light of its limitations. Due to the lack of studies done on the ADG's engagement in technology and technology competence of students in the Middle East in general, this study served solely as an exploratory study to examine the digital literacy competencies of high school students within this region, particularly the UAE. In addition, the sample were exclusively high school students who were of Emirati nationality and came from three private schools in Al Ain. Our results on this sample showed that even though the students have extensive access to technology, they don't use it for advanced knowledge seeking and skills. Considering these sample specifications, this preliminary study's findings is not reflective of the typical ethnically and culturally diverse UAE student population and may not be generalizable to UAE students in other educational and geographic contexts.

In hindsight, two concepts should be adjusted and elaborated in future research. Firstly, is an expansion of the student sample group to allow a more elaborate investigation into the UAE's diverse student population and complex educational landscape. The study should be conducted on both public and private school sectors and feature ethnically diverse student samples. The research should also explore the contribution of different school systems and curricula on the development of digital literacy in students. Additionally, the student sample group were based in $\mathrm{Al}$ Ain so in turn, future research should expand across other cities in the UAE. Assuming increased technological engagement takes place at a larger scale in higher study institutions, future research may also focus on university student samples on the undergraduate level. This may allow the us to look at digital literacy in the ADG as an evolutionary construct across different age groups.

Secondly, future research should use more elaborate research methodologies and theoretical framework. As mentioned above, this study was an essentially a exploratory one. So in future research, calibrating students self-perceived competence and literacy with their actual performance is essential for a more exploratory and multi-level investigation. Another limitation is the research material that was used to survey the students. The use of two surveys and basing the study primarily on the theoretical framework of Erstad and Deursen may have led to a common method bias. Future research will consider a more expansive look into theoretical framework of digital literacy and its scholars to ensure a more elaborate investigation of the ADG and their digital literacy.

\section{Conclusion}

The ubiquitous ownership of digital devices; access to digital technologies and services; and active use of digital media currently drive the behavior of the ADG that is characterized by the activities of frequently connecting, communicating, and clicking which is largely content-centric and online community-oriented. In this regard, the ADG demonstrate some of the attributes of Digital Natives.

This affirms the ADG as a geographic segment of the global generational change brought about by the revolution in digital technology. The ADG is here to stay and the knowledge of both the extent of technology use and the potential social and psychological implications of plasticity can be harnessed to leverage the technology and change potentials of the ADG in reinforcing their social and academic skills to stimulate greater potential engagement in a digital economy. This would entail the creation of a third 
space that is enabled by the positive interaction of the home, school, and the community that would bridge the online and offline experiences of the ADG. The ADG, therefore, represents a significant demographic that should be taken into account in making policy choices involving the family, educational system, economy, and general welfare of the UAE society as a whole.

\section{Declaration of Conflicting Interests}

The authors declared no potential conflicts of interest with respect to the research, authorship, and/or publication of this article.

\section{Funding}

The authors received no financial support for the research, authorship, and/or publication of this article.

\section{References}

Ala-Mutka, K. (2011). Mapping digital competence: Towards a conceptual understanding. Available at: ftp.jrc.es/EURdoc/JRC67075 TN.pdf

Alkaabia, S., Albion, P., \& Redmond, P. (2016). Blended learning in the UAE: development of an adaptability model. Asia Pacific Institute of Advanced Research, 2(1), 45-62.

Arden, J.B. (2010). Rewire your brain: Think your way to a better life. John Wiley \& Sons.

Ashraf, S., \& Perez-Vega, R. (2015). Insight into Dubai’s Generation Y online shopping behaviors: Exploring the limitations of the technology acceptance model with the Digital Natives. International Conference on Organization and Management 2015. Abu Dhabi.

Becerra, J. (2017). The digital revolution is not about technology-it's about people. World Economic Forum, 28(3).

Brosdahl, D.J., \& Carpenter, J.M. (2011). Shopping orientations of US males: a generational cohort comparison. Journal of Retailing and Consumer Services, 18(6), 548-554.

https://doi.org/10.1016/j.jretconser.2011.07.005

Bullen, M., Morgan, T., Belfer, K., \& Qayyum, A. (2009). The net generation in higher education: Rhetoric and reality. International Journal of Excellence in E-Learning, 2(1), 1-13.

Carsten, A., \& Beck, J. (2005). Get ready for the Gamer Generation. Tech Trends, 49(3), 22-25.

https://doi.org/10.1007/BF02763643

Cole, J. (2015). The new Arabs: How the millennial generation is changing the Middle East. Simon and Schuster.

De Fazio, T., \& Ketenon, A. (2012). Quality assurance in a consortium: Open universities Australia. Quality assurance and accreditation in distance education and e-learning: Models, policies and research, 124.

Di Cesare, D.M., Harwood, D., \& Rowsell, J. (2016). It Is Real Colouring?: Mapping Children's Im/Material Thinking in a Digital World. In Handbook of Research on the Societal Impact of Digital Media (69-93). IGI Global. https://doi.org/10.4018/978-1-4666-8310-5.ch004

Doidge, N. (2007). The brain that changes itself: Stories of personal triumph from the frontiers of brain science. Penguin.

Egbo, O.P., Okoyeuzu, C.R., Ifeanacho, I.C., \& Onwumere, J.U. (2011) Gender Perception and Attitude towards E- Learning: A Case of Business Students, University of Nigeria. International Journal of Computer Application, 1, 135-148

Elam, J.R., \& Nesbit, B. (2012). The effectiveness of project-based learning utilizing Web 2.0 tools in EFL. Jaltcall Journal, 8(2), 113-127. 
Erstad, O. (2015). Educating the Digital Generation-Exploring Media Literacy for the 21st Century. Nordic Journal of Digital Literacy, 10. 85-102.

Eshet-Alkalai, Y. (2004). Digital literacy: a conceptual framework for survival skills in the digital era. Journal of Educational Multimedia and Hypermedia, 13(1), 93-106.

Eshet-Alkalai, Y. (2012). Thinking in the digital era: A revised model for digital literacy. Issues in Informing Science and Information Technology, 9(2), 267-276. https://doi.org/10.28945/1621

Export.gov (2019). United Arab Emirates Education. Available at: https://www.export.gov/article?id=United-Arab-Emirates-Education

Ferrari, A. (2012). Digital competence in practice: An analysis of frameworks. Seville: JRC-IPTS.

Ferri, P., Scenini, F., Costa, E., Mizzella, S., Cavalli, N., \& Pozzali, A. (2008). Snack. Culture? La dieta digitale degli studenti universitari. Milano: Università Milano Biccoca

Friedrich, R., Peterson, M., Koster, A., \& Blum, S. (2010). The rise of Generation C Implications for the world of 2020. Booz \& Company, 24.

Gilbert, P. (2018). Impatient, dynamic Generation Z's role in a Digital Africa. Available at: https://www.itweb.co.za/content/WnpNgq2A2wnMVrGd

Goswami, A., \& Dutta, S. (2016). Gender differences in technology usage-A literature review. Open Journal of Business and Management, 4(01), 51-59. https://doi.org/10.4236/ojbm.2016.41006

Grigoryan, T., \& Babayan, N. (2015). Digital natives and digital immigrants in a paperless classroom. International Journal of Arts \& Sciences, 8(1), 289.

Hogan, P., Carlson, B.R., \& Kirk, C. (2015). Open Educational Practices' Models using Open Educational Resources, presented at Open Education Global Consortium Conference. NMU Commons, Banff, Alberta, Canada. 2015, April

Hootsuite (2018). Digital in 2018. Hootsuite. Available at: http://www.hootsuite.com

Howe, N., \& Strauss, W. (1991). Generations: The bistory of America's future. New York: Quill.

Howe, N., \& Strauss, W. (2003). Millennials go to college: strategies for a new generation on campus. Washington DC: American Association of Collegiate Registrars and Admission Officers.

Iran, H. (2011). A study on educational technology in Dubai, challenges, and suggested solutions. Faculty of Engineering and IT. Dubai: The British University in Dubai.

Islam, M.A., Rahim, N.A.A., Liang, T.C., \& Montaz, H. (2011) Effect of Demographic Factors on E-Learning Effectiveness in a Higher Learning Institution in Malaysia. International Education Studies, 4, 112-122. https://doi.org/10.5539/ies.v4n1p112

Jackson, L.A., Zhao, Y., Kolenic III, A., Fitzgerald, H.E., Harold, R., \& Von Eye, A. (2008). Race, gender, and information technology use: The new digital divide. Cyber Psychology \& Behavior, 11(4), 437-442. https://doi.org/10.1089/cpb.2007.0157

Jewels, T., \& Albon, R. (2011). Reconciling culture and digital literacy in the United Arab Emirates. International Journal of Digital Literacy and Digital Competence (IJDLDC), 2(2), 27-39. https://doi.org/10.4018/jdldc.2011040103

Johnson, S. (2006). Everything bad is good for you: How today's popular culture is actually making us smarter. Penguin.

Jones, C., \& Cross, S. (2009). Is There a net generation Coming to University? In ALT-C 2009 'In dreamsbegins responsibility": Choice, evidence and change. Manchester, UK. 
Jones, C., Ramanau, R., Cross, S., \& Healing, G. (2010). Net generation or Digital Natives: Is there a distinct new generation entering university?. Computers \& education, 54(3), 722-732.

https://doi.org/10.1016/j.compedu.2009.09.022

Jones, N., Blackey, H., Fitzgibbon, K., \& Chew, E. (2010). Get out of MySpace! Computers \& Education, 54(3), 776-782. https://doi.org/10.1016/j.compedu.2009.07.008

Kennedy, G., Dalgarno, B., Bennet, S., Judd, T., Gray, K., \& Chang, R. (2008). Immigrants and natives: Investigating differences between staff and students' use of technology. Ascilite Annual Conference. Melbourne. Available at: http://www.ascilite.org.au/conferences/melbourne08/procs/kennedy.pdf

Kennedy, G., Judd, T., Dalgarno, B., \& Waycott, J. (2010). Beyond natives and immigrants: exploring types of net generation students. Journal of Computer Assisted Learning, 26(5), 332-343.

https://doi.org/10.1111/j.1365-2729.2010.00371.x

Kim, D., \& Ammeter, A. (2018). Shifts in online consumer behavior: A preliminary investigation of the Net Generation. Journal of Theoretical and Applied Electronic Commerce Research, 13(1), 1-25. https://doi.org/10.4067/S0718-18762018000100102

Lankshear, C., \& Knobel, M. (2003). New literacies: Changing knowledge and classroom learning. Open University Press.

Lenhart, A., Rainie, L., \& Lewis, O. (2001). Teenage life online: The rise of the Internet Messaging Generation and the Internet's impact on friendship and family relations. Washington DC: PeW Internet and American Life Project.

Leung, L. (2004). Net-generation attributes and seductive properties of the internet as predictors of online activities and internet addiction. CyberPsychology \& Behavior, 7(3), 333-348. https://doi.org/10.1089/1094931041291303

Li, Y., \& Ranieri, M. (2010). Are 'digital natives' really digitally competent? - A study on Chinese teenagers. British Journal of Educational Technology, 41(6), 1029-1042. https://doi.org/10.1111/j.1467-8535.2009.01053.x

Liaw, S.S., \& Huang, H.M. (2011) A Study of Investigating Learners' Attitudes toward E-Learning. Proceedings of the 5th International Conference on Distance Learning and Education, 12, 28-32.

Lorenzo, G., Oblinger, D., \& Dzubian, C. (2006) How Choice, Co-Creation, and Culture Are Changing What it means to Be Net Savry, ELI Paper 4. Available at: https://er.educause.edu/articles/2007/1/how-choicecocreation-and-culture-are-changing-what-it-means-to-be-net-savvy

Lusoli, W., \& Miltgren, C. (2009). Young people and emerging digital services; an exploratory survey on motivations, perceptions, and acceptance of risks. In Lusoli, W., \& Maghorios, I. (Eds.) JRC Scientific and Technological Reports. Seville, Spain: Spain Institute of Prospective Technology Studies.

Macalister, J., \& Nation, I.S.P. (2009). Language curriculum design. Routledge.

Marcu, S. (2016). Learning mobility challenging borders: Cross-border experiences of Eastern European Immigrants in Spain. Mobilities, 11(3), 343-361. https://doi.org/10.1080/17450101.2014.934055

Margaryan, A., \& Littlejohn, A. (2008). Are digital natives a myth or reality?: Students' use of technologies for learning. Available at: http://www.academy.gcal.ac.uk/anoush/documents/DigitalNativesMythOrRealityMargaryanAndLittlejohn-draft-111208.pdf

Martin, J. (2013). Technology, education and Arab youth in the 21st century: A study of the UAE. Ph.D. thesis. The University of Queensland, School of Education, Queensland.

Mazman, S.G., \& Usluel, Y.K. (2011) Gender Differences in Using Social Networks. The Turkish Online Journal of Educational Technology, 10, 133-139 
McNaught, C., Lam, P., \& Ho, A. (2009). The digital divide between university students and teachers in Hong Kong. In Same places, different spaces. Proceedings ascilite Auckland 2009. Available at: http://www.ascilite.org.au/conferences/auckland09/procs/mcnaught.pdf

Ministry of Education (2010). Ministry of Education Strategy 2020. Available at: https://www.moe.gov.ae/Arabic/Docs/MOE\%20 Strategy.pdf

Moselen, C., \& Wang, L. (2014). Integrating information literacy into academic curricula: A professional development programme for librarians at the University of Auckland. The Journal of academic librarianship, 40(2), 116-123. https://doi.org/10.1016/j.acalib.2014.02.002

Murray, M.C., \& Pérez, J. (2014). Unraveling the digital literacy paradox: How higher education fails at the fourth literacy. Issues in Informing Science and Information Technology, 11, 85. https://doi.org/10.28945/1982

$\mathrm{Ng}$, W. (2012). Can we teach digital natives digital literacy? Computers \& Education, 59(3), 1065-1078. https://doi.org/10.1016/j.compedu.2012.04.016

Oblinger, D., Oblinger, J.L., \& Lippincott, J.K. (2005). Educating the net generation. Boulder, Colo. EDUCAUSE, c2005. 1 v.(various pagings): Illustrations.

Olivia (2013). Abu Dhabi Education Council. New school model. Available at: https://www.khaleejtimes.com/nation/education/abu-dhabi-rolls-out-new-school-model

Ong, C.S., \& Lai, J.Y. (2006). Gender differences in perceptions and relationships among dominants of e-learning acceptance. Computers in Human Behavior, 22(5), 816-829.

https://doi.org/10.1016/j.chb.2004.03.006

Palfrey, J.G., \& Gasser, U. (2008). Born digital: Understanding the first generation of digital natives. A Member of the Perseus Books Group, New York. Retrieved from; www.ReadHowYouWant.com

Parkman, S., Litz, D., \& Gromik, N. (2018). Examining pre-service teachers' acceptance of technologyrich learning environments: A UAE case study. Education and Information Technologies, 1-23. https://doi.org/10.1007/s10639-017-9665-3

Pedro, F. (2009). New Millennium learners in higher education: evidence and policy implications. Paris: Center for Educational Research and Innovation.

Porat, E., Blau, I., \& Barak, A. (2018). Measuring digital literacies: Junior high-school students' perceived competencies versus actual performance. Computers \& Education, 126, 23-36.

https://doi.org/10.1016/j.compedu.2018.06.030

Prensky, M. (2001). Digital Natives, Digital Immigrants. On the Horizon, 9(5), 1-6.

https://doi.org/10.1108/10748120110424816

Ramey, K. (2008). Undergraduate perceptions of characteristics attributed to Millennial Generation college students and implications for university recruitment and retention. Thesis. Texas Tech University.

Rosen, L. (2010). Rewired: Understanding the i-Generation and the way they learn. New York: Palgrave-Macmillan.

Rowlands, I., Nicholas, D., Williams, P., Fieldhouse, M., Gunter, M., Withey, B. et al. (2008). The Google generation: the information behavior of the researcher of the future. Aslib Proceeding, 60(4), 290-310. https://doi.org/10.1108/00012530810887953

Sabbagh, K., Mourad, M., Kabbara, W., Shehadi, R., \& Samman, H. (2012). Understanding the Arab Digital Generation. Booz \& Company.

Salajan, F., Schonwetter, D., \& Cleghorn, B. (2010). Student and faculty inter-generational divide: Fact or fiction. Computers and Education, 55(3), 1393-1403. https://doi.org/10.1016/j.compedu.2010.06.017 
Sanchez, J., Salinas, A., Contreras, D., \& Meyers, E. (2010). Does the digital generation of learners exist? A qualitative study. British Journal of Educational Technology. https://doi.org/10.1111/j.1467-8535.2010.01069.x

Santrock, J. (2008). Adolescence. New York: Mc-Graw-Hill.

Schultz, H., Block, M., \& Schultz, D. (2013). Understanding China's Digital Generation: A marketeers' guide to understanding young Chinese consumers. Worthington: Prosper Publishing.

Schulmeister, R. (2008). Is There a Net Gener in the House? Dispelling a Mystification. E-learning and Education, 4(5).

Selwyn, N. (2008). An investigation of differences in undergraduates' academic use of the internet. Active Learning in Higher Education, 9(1), 11-22. https://doi.org/10.1177/1469787407086744

Shao, B. (2010). University students' use of technologies in China. Paper presented at The European Conference on Educational Research 2010: Education and Culture Change. Helsinki.

Singh, A., \& Dangmei, J. (2016). Understanding Generation Z: the future workforce. Southeast Asian Journal of Multidisciplinary Studies, 3(3), 242-246.

Small, G., \& Vorgan, G. (2009). iBrain: surviving the technological alteration of the modern mind. New York: Harper.

Smith, S.D., \& Borreson-Caruso, J. (2010). The ECAR Study of Undergraduate Students and Information Technology, 2010 (Research Study, 6). Boulder, CO: EDUCASE Center for Applied Research. Available at: http://www.educause.edu/ecar

Smith, S., Salaway, G., \& Borreson-Caruso, J. (2009). The ECAR Study of Undergraduate Students and Information Technology (Research Study, 6). Boulder, CO: EDUCASE Center for Applied Research. Retrieved from http://www.educause.edu/ecar

Srivastava, R., \& Rauta, F. (2017). Social media analysis of higher education institutions in the UAE. International Journal of applied information Systems, 12(6), 16-20.

Suri, G., \& Sharma, S. (2013) The Impact of Gender on Attitude towards Computer Technology and E-Learning: An Exploratory Study of Punjab University, India. International Journal of Engineering Research, 2, 132-136.

Tapscott, D. (1998). GrowingUp Digital: The Rise of the net Generation. New York: McGraw-Hill.

Tapscott, D. (2009). Grown up digital: How the Net Generation is changing your world. New York: McGraw-Hill.

Thiefoldt, D., \& Scheef, D. (2004). Generation X and the Millennials: What you need to know about mentoring the new generations. In Article adapted from workshop "Engaging the Generations" (pp. 5-7).

Thinyane, H. (2010). Are digital natives a world-wide phenomenon? An investigation into South African first-year students' use and experience with technology. Computers \& Education, 55(1), 406-414. https://doi.org/10.1016/j.compedu.2010.02.005

UAE Cabinet (2019). Mohammed Bin Rashid Smart Learning Programme, Available at: https://www.uaecabinet.ae/en/details/prime-ministers-initiatives/mohammed-bin-rashid-smart-learningprogramme

Van den Beemt, A., Akkerman S., \& Simons P.R.J. (2010) The use of interactive media among today's youth: results of a survey. Computers in Human Behavior, 26, 1158-1165.

https://doi.org/10.1016/j.chb.2010.03.022

Van Deursen, A.J.A.M., Courtois, C., \& Van Dijk, J. (2010). Internet skills. Vital assets in an information society. Enschede, the Netherlands: University of Twente. 
Van Deursen, A.J.A.M., Helsper, E. J., \& Eynon, R. (2014). Measuring digital skills. From digital skills to tangible outcomes. Project Report. Available at: www.oii.ox.ac.uk/research/projects

Vrazalic, L., MacGregor, R., Behl, D., \& Fitzgerald, J. (2009). E-learning barriers in the United Arab Emirates preliminary results from an empirical investigation. IBIMA Business Review, 4(1), 1-6. https://doi.org/10.5171/2010.458727

Veen, W. (2003). A new force for change: Homo zappiens. The Learning Citizen, 7(1), 5-7.

Worley, K. (2011). Educating college students of the net generation. Adult Learning, 22(3), 31-39. https://doi.org/10.1177/104515951102200305

\author{
Published by OmniaScience (www.omniascience.com) \\ Journal of Technology and Science Education, 2020 (www.jotse.org)
}

\title{
(c) $\underset{\mathrm{BY}}{\mathrm{BY}(\mathrm{NC})}$
}

Article's contents are provided on an Attribution-Non Commercial 4.0 Creative commons International License. Readers are allowed to copy, distribute and communicate article's contents, provided the author's and JOTSE journal's names are included. It must not be used for commercial purposes. To see the complete licence contents, please visit https://creativecommons.org/licenses/by-nc/4.0/. 